\title{
Społeczno-kulturowe i ekologiczno-zdrowotne funkcje lasu
}

\author{
Socio-Cultural and Ecological-Health Functions of the Forest
}

\author{
Mariusz Ciszek \\ Wydział Pedagogiki i Psychologii, Akademia Humanistyczno-Ekonomiczna w Łodzi \\ ORCID: https://orcid.org/0000-0003-0294-3048•m.ciszek.contact@gmail.com \\ Zgłoszono: 3.11.2020; zrecenzowano: 12.01.2021; zaakceptowano do druku: 14.01.2021
}

\begin{abstract}
Streszczenie: W artykule zagadnienie lasu zostanie przedstawione w perspektywie społecznej (społeczno-kulturowej). Zazwyczaj las badany jest jako istotny składnik środowiska przyrodniczego. Podejście takie jest słuszne, aczkolwiek w przypadku człowieka taka perspektywa postrzegania środowiska jest niepełna. Człowiek bowiem jest nie tylko organizmem, lecz także osobą i istotą społeczną. Dlatego ludzkim środowiskiem jest środowisko społeczno-przyrodnicze. Taka perspektywa postrzegania ludzkiego środowiska uwzględnia fakt, że człowiek bezpośrednio nie występuje w przyrodzie, lecz w środowisku społecznym (w tym i kulturowym), które z kolei powstało na fundamencie przekształconego i dostosowanego do potrzeb ludzi środowiska przyrodniczego. Człowiek jako (osoba) twórca kultury stworzył środowisko społeczne zawierające bardzo dużo sztucznych elementów. To wyróżnia go spośród innych gatunków żywych, ponieważ ludzkie środowisko naturalne, to nie tylko środowisko przyrodnicze, lecz także sztuczne, kształtowane w ramach społeczeństwa (środowiska społeczno-kulturowego). Wychodząc z tego założenia, w pracy autor postara się ukazać las jako istotny element tak postrzeganego ludzkiego środowiska. Pełni on bowiem w życiu ludzi istotne funkcje społeczne (społeczno-kulturowe), kształtujące również bezpieczeństwo środowiskowe (ekologiczno-zdrowotne). Omówienie tych szczegółowych funkcji i ich podział stanowi cel artykułu.
\end{abstract}

Słowa kluczowe: środowisko społeczno-przyrodnicze, socjologia środowiskowa, psychologia środowiskowa, pedagogika środowiskowa, bezpieczeństwo środowiskowe

\begin{abstract}
The article presents a socio-cultural perspective on the issue of the forest. Usually, the forest is studied as an important component of the natural environment. This approach is correct, although in the case of people, such a philosophy of perceiving the environment in this way is incomplete, since the human being is not only an organism, but also a person and a social being. Therefore, the human environment is a socio-natural environment. This perspective of the human environment takes into account the fact that the human being does not appear directly in nature, but in a social (including cultural) environment, which, in turn, was created on the foundation of a transformed natural environment, adapted to the needs of people. The human being, as a culture creator, produced a social environment containing manifold artificial elements. The above distinguishes him from other living species, because the natural human environment, besides being natural, is also artificial, shaped within the society's socio-cultural environment. Starting from this assumption, the author will try to show the forest as an important element of the perceived human environment. It performs important social and cultural functions in people's lives, which also shape environmental (ecological and health) security. The purpose of the article is to discuss these detailed functions and their division.
\end{abstract}

Keywords: socio-natural environment, environmental sociology, environmental psychology, environmental pedagogy, environmental security 


\section{Wprowadzenie}

Las zazwyczaj stanowi przedmiot badań i zainteresowania nauk leśnych i przyrodniczych. I nic dziwnego, stanowi bowiem ważny element przyrody, zarówno tej w pełni naturalnej (pierwotnej), jak i ukształtowanej przez człowieka. Podejście takie jest słuszne i zrozumiałe, ale w przypadku człowieka taka perspektywa postrzegania środowiska jest niepełna. Człowiek bowiem jako organizm przynależy do środowiska przyrodniczego, ale jako osoba i zarazem istota społeczna należy do środowiska społecznego (społeczno-kulturowego). Stąd też właściwym dla ludzi środowiskiem jest środowisko społeczno-przyrodnicze.

Wychodząc z takiego założenia, autor postara się w artykule ukazać las jako istotny element tak postrzeganego ludzkiego środowiska (dodatkowo ilustrując to na opracowanych przez siebie rysunkach). Las może bowiem być badany również w perspektywie społecznej. W taką optykę wpisuje się niniejsza praca, która postrzega las jako ważny element zarówno środowiska przyrodniczego, jak i społecznego człowieka. Las w środowisku życia człowieka pełni nie tylko ważne funkcje przyrodnicze czy użytkowogospodarcze, lecz także typowo społeczne (społeczno-kulturowe), które kształtują również bezpieczeństwo środowiskowe (ekologiczno-zdrowotne). Omówienie funkcji społecznych (społeczno-kulturowych) lasu i ich podział stanowi cel artykułu.

\section{Zagadnienie środowiska społeczno-przyrodniczego}

Każdy organizm żyje w jakimś środowisku. Dotyczy to również człowieka. Za środowisko można w ujęciu najbardziej ogólnym przyjąć całościowy zespół (nierozerwalnie ze sobą powiązanych rozlicznymi relacjami) elementów, zjawisk, procesów i czynników materialnych (ożywionych i nieożywionych) i niematerialnych (np. stosunków społecznych czy kulturowych), zarówno powstałych w sposób naturalny, jak i wskutek działalności człowieka, występujących na określonej przestrzeni, łącznie stanowiących otoczenie i warunki życia poszczególnych organizmów (osobników) (Olaczek 1999, 249; Bańka 2002, 19; Mazurski 2009, 260). W tak sformułowanej definicji wystarczy zastąpić wyraz „organizm” („osobnik”) słowem „człowiek” i mamy też definicję środowiska człowieka, które w jego przypadku jest środowiskiem społeczno-przyrodniczym.

Dla dzikich gatunków roślinnych czy zwierzęcych naturalnym środowiskiem ich życia jest przyroda. Natomiast w przypadku człowieka (będącego osobą i istotą społeczną) powinno mówić się o środowisku społeczno-przyrodniczym, a nie tylko o wąsko pojmowanym środowisku przyrodniczym czy społecznym. Ludzki gatunek żyje bowiem również w granicach stworzonego przez siebie środowiska społecznego. Stąd też tradycyjnie uprawiane nauki społeczne, takie jak chociażby socjologia czy psychologia społeczna, a jeszcze przed ich powstaniem klasyczna filozofia społeczna, koncentrowały się na zagadnieniu ludzkiego społeczeństwa stanowiącego płaszczyznę ludzkiego życia. Taka perspektywa choć zrozumiała jest jednak także niepełna. Człowiek bowiem nadal uzależniony jest od środowiska przyrodniczego stanowiącego podstawę dla utrzymania i rozwoju ludzkiego życia, zarówno w wymiarze jednostkowym, gatunkowym, jak i społecznym czy gospodarczym.

Współcześnie za sprawą społecznych nauk środowiskowych, takich jak chociażby socjologia środowiskowa czy społeczna psychologia środowiskowa, zwrócono uwagę na rolę przyrody (środowiska przyrodniczego) w środowisku życia społecznego człowieka. Nauki te badają różnorodne relacje i zależności między człowiekiem a jego środowiskiem naturalnym, w tym i funkcje, jakie pełni przyroda (i jej elementy) względem świata społecznego ludzi. I chociaż dyscypliny te nie stanowią monolitu, gdyż w ich obrębie można spotkać się z mnogością różnorodnych mniej lub bardziej „głębokich” pod względem środowiskowym koncepcji i teoretycznych stanowisk, to słusznie zwracają uwagę, iż środowisko przyrodnicze obok środowiska społecznego (w tym 
i środowiska fizyczno-przestrzennego zbudowanego przez ludzi) tworzy środowisko życia człowieka, wpływając na życie ludzi. Podobnie wygląda sytuacja w różnych współczesnych nurtach szeroko pojmowanej ekologii humanistycznej, które łączy to, iż dostrzegają wartość i znaczenie środowiska przyrodniczego. Tego typu nauki dają nam możliwość wypracowania nowego, całościowego spojrzenia na istotę ludzkiego środowiska (Bubolz and Sontag 1993, 419-448; Bańka 2002, 19, 25; Dołęga 2003, 7-11; Ciszek 2013; Bowden 2017, 1-11).

Taka nowa i szeroka perspektywa postrzegania ludzkiego środowiska - przyjęta w niniejszym artykule - uwzględnia fakt, iż człowiek bezpośrednio nie występuje w przyrodzie, lecz w środowisku społecznym (w tym i kulturowym), które powstało (wskutek działalności kulturowej człowieka) na fundamencie przekształconego i dostosowanego do potrzeb ludzi środowiska przyrodniczego. Człowiek, jako twórca kultury, stworzył środowisko społeczne zawierające bardzo dużo sztucznych elementów. To wyróżnia człowieka spośród innych gatunków żywych, gdyż ludzkie środowisko naturalne to nie tylko środowisko przyrodnicze, lecz także sztuczne, rozwijane w ramach społeczeństwa (środowiska społeczno-kulturowego). Człowiek, jako organizm, należy pod tym względem do przyrody i do jej uwarunkowań (praw przyrody, z której jako podstawy czerpie wszystkie niezbędne oży- wione i nieożywione składniki do biologicznego życia i rozwoju itp.). Natomiast jako istota społeczna i ludzka osoba podlega prawom i regułom społecznym i kulturowym, określającym życie społeczne i warunkujące rozwój osobowy. Człowiek zatem, z jednej strony, potrzebuje przyrody do życia, bez której obyć się nie może (w przeciwieństwie do niej samej) - dlatego powinien ją zawsze chronić. Z drugiej zaś strony potrzebuje też środowiska społeczno-kulturowego niezbędnego do życia społecznego i osobowego, o którego jakość również musi zabiegać, gdyż w nim bezpośrednio występuje. Środowisko naturalne człowieka jest zatem stworzone z dwóch wielkich, oddziałujących na siebie elementów środowiska społecznego (społeczno-kulturowego) i środowiska przyrodniczego, co można przedstawić w graficzny sposób (rys. 1).

Tak całościowo rozumiane środowisko społeczno-przyrodnicze, a w zasadzie naturalne środowisko człowieka (ludzkie środowisko), składa się ze środowiska przyrodniczego (stanowiącego wytwór natury) oraz zintegrowanego z nim środowiska społecznego (a właściwie społeczno-kulturowego) - stanowiącego ludzki wytwór i miejsce bezpośredniego występowania człowieka. Środowisko przyrodnicze obejmuje zarówno ożywione elementy przyrody (biotyczne), jak i nieożywione (abiotyczne). Te pierwsze składają się na jego subśrodowisko biologiczne (żywe; złożone z materii

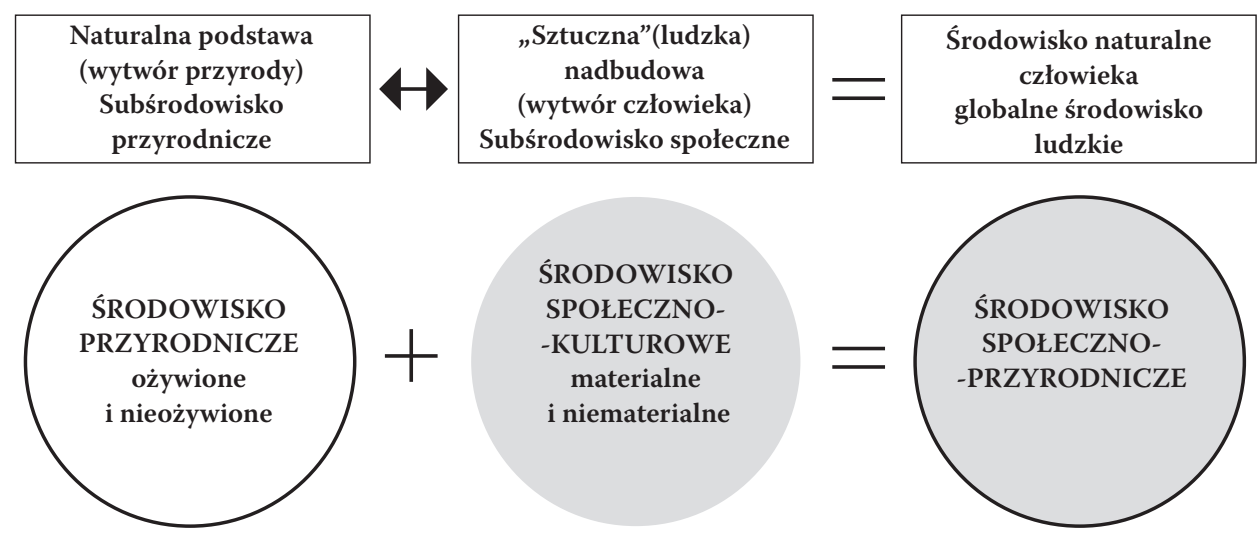

Rysunek 1. Środowisko społeczno-przyrodnicze jako naturalne środowisko człowieka 
organicznej, organizmów), te drugie zaś na fizyczne czy fizykochemiczne (martwe; złożone z materii nieożywionej i tego typu fizykochemicznych składników, kształtujących siedlisko dla ożywionej przyrody). W tę przyrodniczą (biofizyczną) podstawę łącznie ujmowanego subśrodowiska przyrodniczego, wbudowane (wtopione) jest subśrodowisko społeczne (społeczno-kulturowe) - zob. rys. 1. Złożone jest ono z elementów materialno-przestrzennych, jak i niematerialnych (duchowych) stworzonych i przekształconych przez ludzi (a więc elementów „nieożywionych”, „sztucznych”) oraz samych ludzi („żywych jednostek”) pozostających w różnych stosunkach wobec siebie, jak i otaczających ich rzeczy (relacji międzyosobowych i społeczno-kulturowych). Dopiero wszystkie te składniki (przyrodnicze i społeczne) razem wzięte (wraz z ich wszystkimi uwarunkowaniami, mechanizmami i spełnianymi przez nie funkcjami) w przypadku ludzi stanowią globalne, naturalne środowisko życia człowieka (środowisko ludzkie).

Pomiędzy tymi dwoma typami subśrodowisk zachodzi pewien stopień analogii. Zarówno środowisko przyrodnicze, jak i społeczne ma wymiar nieożywiony (np. subśrodowisko fizykochemiczne czy fizyczno-przestrzenne ludzi), jak i ożywiony (organizmy żywe; ludzie) oraz materialny (materia fizyczna lub biologiczna czy ludzkie wytwory kultury materialnej) i niematerialny (naturalna przestrzeń tudzież ludzkie wytwory kultury duchowej). Ponadto pomiędzy tymi subśrodowiskami i ich elementami zachodzą wzajemne oddziaływania oraz powinna występować tam względna, dynamiczna społeczno-przyrodnicza równowaga (homeostaza) - zob. rys. 1 (jest ona obecnie najczęściej zachwiana na szkodę przyrody). Dotyczy to również lasu, który jest bardzo ważnym elementem przyrody, ale również i środowiska społecznego, dla którego pełni wiele ważnych i doniosłych funkcji. Przyroda jest zatem elementem aktywnym (a nie tylko statycznym pojmowanym jako przestrzeń zajmowana przez ludzkie populacje, które jednostronnie oddziałują na przyrodę).

\section{Las elementem środowiska społeczno- przyrodniczego}

Nie ma żadnych wątpliwości, że las jest bardzo ważnym elementem środowiska przyrodniczego. Nawiązując jednak do wcześniej przedstawionej koncepcji środowiska społeczno-przyrodniczego, w myśl której do ludzkiego środowiska społecznego przynależy również przyroda, to las musi stanowić pośrednio element tegoż całościowo pojmowanego naturalnego środowiska człowieka. Las, stanowiąc element przyrody, wchodzi jednocześnie w skład otoczenia społecznego ludzi. Jest zatem społeczno-przyrodniczym elementem (a nie tylko przyrodniczym) ludzkiego, naturalnego środowiska (rys. 2).

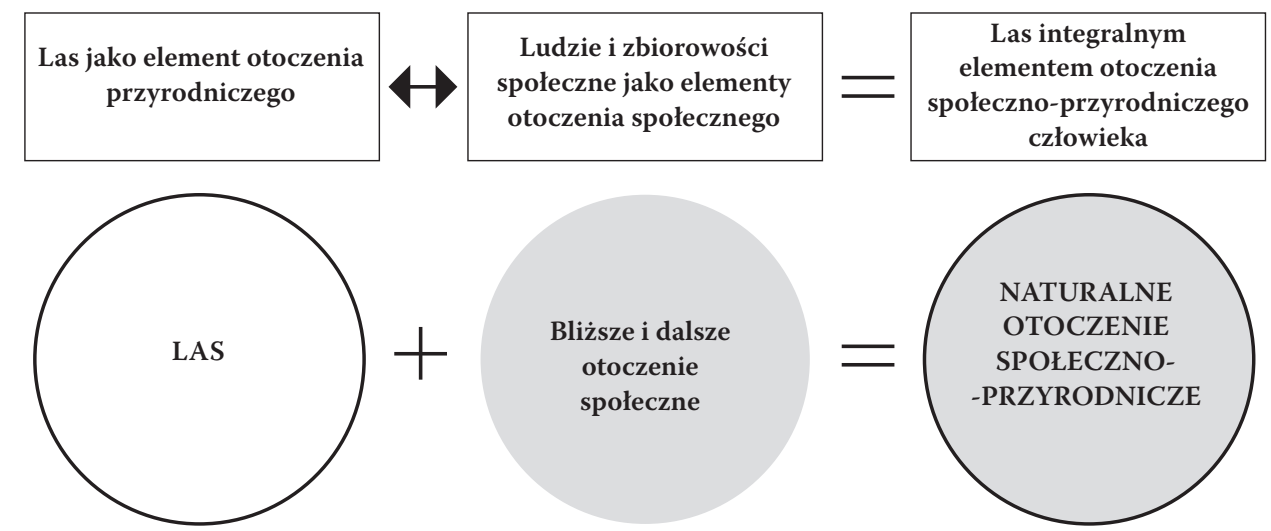

Rysunek 2. Las jako element naturalnego otoczenia społeczno-przyrodniczego człowieka 
Należy zatem stwierdzić, iż pomiędzy lasem a społeczeństwem (czy też poszczególnymi ludzkimi zbiorowościami wchodzącymi w jego skład) zachodzą wzajemne oddziaływania (zob. rys. 3). Ludzie i tworzone przez nich społeczeństwo oddziałują zwrotnie na las, a środowisko leśne na ludzi (wzajemne oddziaływania). Tego typu uwagi pozostają w zgodzie z zasygnalizowaną wcześniej koncepcją środowiska społeczno-przyrodniczego człowieka, w którym las, jako element środowiska przyrodniczego, aktywnie oddziałuje na środowisko społeczne, a ono z kolei na środowisko leśne (zob. rys. 2 i 3). Las zresztą może być w pełni naturalny - pierwotny (np. puszcze, dżungle), stanowiący element pierwotnej przyrody (samoistnie przez nią uformowany), jak i być zasadzony i ukształtowany przez człowieka (las jako typowy element społeczno-przyrodniczy).

Obecnie las jest tylko bliższym lub dalszym otoczeniem dla ludzkich zbiorowości, ale kiedyś jego wpływ na ludzkie życie był jeszcze większy. Wynika to z rozwoju współczesnych społeczeństw, które bezpośrednio występują w formie organizacyjnej dużych państw narodowych, ale kiedyś ich występowanie w naturze było znacznie większe. Dotyczyło to również lasu, z którym społeczeństwa mniej rozwinięte korzystały i koegzystowały w znacznie większym stopniu niż obecnie (tego typu społeczeństwa o charakterze myśliwsko-zbierackim jeszcze występują np. na obszarze Ameryki Południowej, w dżungli amazońskiej - choć są już na wyginięciu. Las (pierwotny) na życie takich małych społeczeństw wywierał jeszcze większy wpływ niż obecnie. Czasami bywał nawet ich domem lub integralnym, najbliższym otoczeniem (adoptowanym na miarę możliwości i potrzeb). Oczywiście korzystały one z jego - wydawałoby się niewyczerpalnych bogactw - na wiele sposobów, nie tylko jako miejsce schronienia, lecz także jako rezerwuar pożywienia i wielu cennych surowców niezbędnych do życia i zdrowia. Las także oddziaływał na ich system wierzeń. I choć tego typu społeczeństwa nie były raczej miłośnikami przyrody zachwycającymi się nad jej pięknem i dostrzegającym w niej immanentną wartość (Korbel 2005, 7-8), to jednak w praktyce ich mały rozwój cywilizacyjny nie powodował naruszenia równowagi przyrodniczej lasów.

Dopiero z czasem, wraz z dynamicznym rozwojem cywilizacyjnym ludzi, powstał taki problem, z jednej strony powodując nie tylko zjawisko niszczenia i kurczenia, lecz także prowadząc w wielu rozwiniętych przemysłowo krajach nawet do zaniku występowania obszarów leśnych. Z drugiej strony, współczesne społeczeństwa - ograniczone (ze swojej własnej winy) dostępnością do lasów - zaczęły dostrzegać w nich oprócz tradycyjnych, użytkowych funkcji - nowe i to zarówno typowo przyrodnicze, jak i społeczno-kulturowe funkcje, zauważając również piękno lasów i ich wewnętrzną wartość.

Pomimo że współcześnie doszło do rozluźnienia związków człowieka z przyrodą, to jednak las (zarówno ten coraz rzadziej spotykany w pełni naturalny - pierwotny, jak i w określonym stopniu ukształtowany przez człowieka) nadal oddziałuje na życie ludzi, pełniąc wiele nie tylko produkcyjnych, lecz

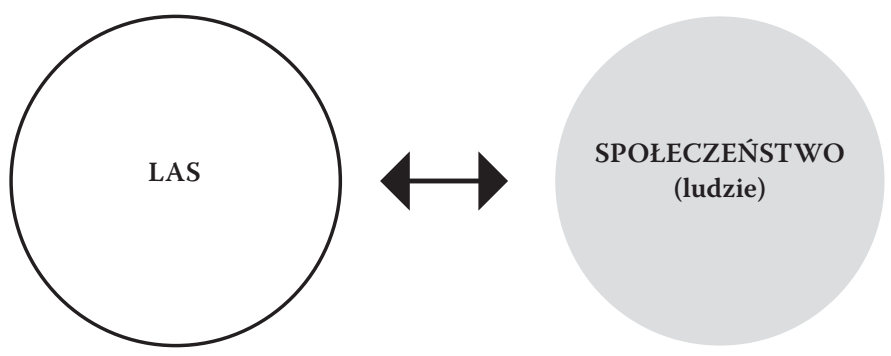

Rysunek 3. Wzajemne oddziaływanie między lasem a społeczeństwem 
także pozaprodukcyjnych (w tym i społecznych czy psychospołecznych oraz kulturowych) funkcji, na których warto się poniżej skupić.

\section{Funkcje społeczne (społeczno- kulturowe) lasu}

Jak wiadomo, las pełni wiele pozytywnych funkcji. Na ogół mówi się o funkcjach produkcyjnych (gospodarczych), związanych z dostarczaniem surowca drzewnego i innych leśnych płodów. W sensie socjologicznym tego typu funkcje produkcyjne mają wymiar materialny i powiązane są z obszarem kultury materialnej. Istnieją też funkcje pozaprodukcyjne lasu, które dzielą się na ekologiczne (środowiskotwórcze) kształtujące środowisko przyrodnicze - oraz społeczne (socjalne), powiązane ze środowiskiem społecznym (społeczno-kulturowym) człowieka (Przybylska 2005, 101-103).

Interesujące nas tutaj społeczne funkcje lasu dotyczą wpływu lasu (środowiska leśnego) na fizyczny i duchowy rozwój społeczeństwa (Przybylska 2005, 103). Ten rozwój przebiega też w płaszczyźnie psychospołecznej, gdyż las oddziałuje również na psychiczny rozwój człowieka (ludzi tworzących społeczeństwo), co literatura przyrodnicza zazwyczaj pomija. Tak szeroko pojmowane funkcje społeczne (społeczno-kulturowe) lasu, wzajemnie na siebie oddziałujące, można przedstawić graficznie (rys. 4). Warto omówić tak rozumiane społeczne funkcje lasu (koncentrując się na tych podstawowych).

\subsection{Funkcje fizyczne}

Las pełni szereg ważnych funkcji zdrowotnych dla życia i rozwoju fizycznego człowieka, a w skali zbiorowej dla całego społeczeństwa. Bezpośredni kontakt z lasem, jak i wpływ jego przyrodniczego bogactwa na bliższe i dalsze otoczenie społeczne ludzi oddziałują przede wszystkim na zdrowie jednostki oraz całej populacji, zarówno w aspekcie profilaktycznym, jak i uzupełniającym leczenie farmakologiczne. Las charakteryzuje się specyficznym mikroklimatem, a aromat olejków eterycznych i dźwięki leśnych mieszkańców pozwalają ulżyć w cierpieniu. W otoczeniu lasów powstają też uzdrowiska, las bowiem jest takim naturalnym uzdrowiskiem i sanatorium (Przybylska $2005,103)$. Las zatem chroni przed negatywnymi skutkami cywilizacji, ponieważ (PyłkaGutowska 2000, 194-196):

- wzbogaca powietrze w tlen, pełniąc rolę filtra dla różnorodnych zanieczyszczeń atmosferycznych, oraz "produkuje" tlen (stąd też nazywane są "zielonymi płucami");

- tłumi hałas, stanowiąc naturalną przeszkodę obniżającą poziom hałasu;

\section{SPOŁECZNE (SPOŁECZNO-KULTUROWE) FUNKCJE LASU}

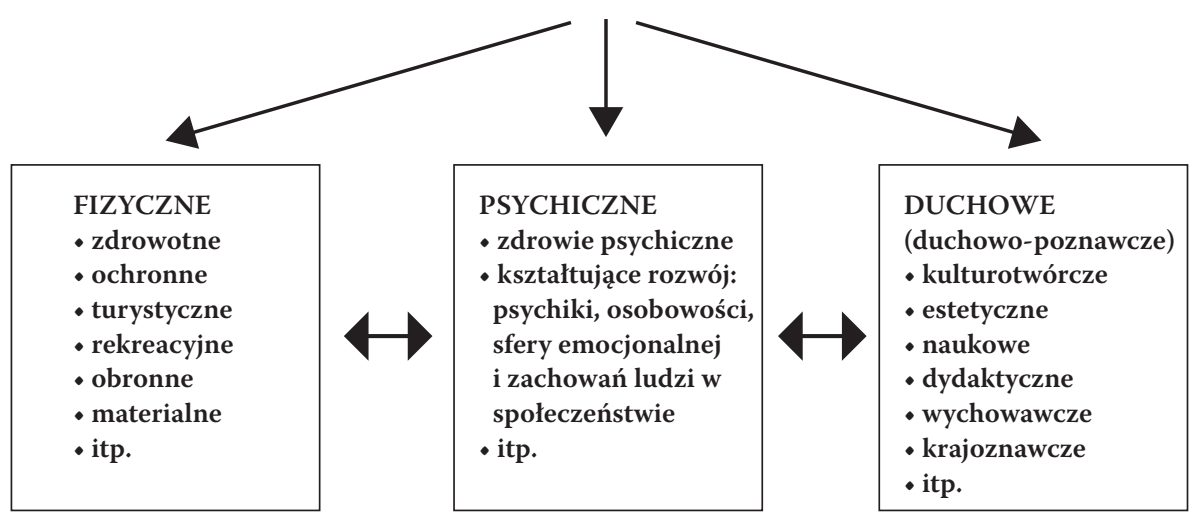

Rysunek 4. Społeczne (społeczno-kulturowe) funkcje lasu 
- wydziela do atmosfery substancje bakteriobójcze (fitoncydy);

- $\quad$ wpływa na jonizację powietrza;

- zapewnia wypoczynek i rekreację.

Lasy pełnią zatem funkcje zdrowotne i jednocześnie ochronne, chroniąc społeczeństwo przed niekorzystnymi następstwami rozwoju cywilizacyjnego (czyli chroni ludzi przed nimi samymi). Te zdrowotne funkcje lasu wspiera aktywność o charakterze turystyczno-rekreacyjnym, która umożliwia bezpośredni kontakt z lasem, prowadząc do regeneracji sił oraz wzmocnienia fizycznej wydolności organizmu i ludzkiej woli poprzez różne formy sportu „na powietrzu" (Kiełczewski i Wiśniewski 1982, 150152). Przyczyniają się do tego również różne rekreacyjne formy zbieractwa runa leśnego. Funkcje turystyczno-rekreacyjne wspierają również rozwój kultury fizycznej, a więc mają charakter kulturotwórczy, z tym że dotyczy to obszaru kultury materialnej.

Lasy - o czym wiemy z historii - służyły jako ważny element systemu obronnego Polski, mając pozytywny wpływ na bezpieczeństwo narodowe kraju (funkcje obronne). Kiedyś rozległe i trudne do przebycia puszcze stanowiły naturalną granicę kraju, chroniąc państwo przed podbiciem. To w głębinach rozległych kompleksów leśnych chronili się partyzanci, którzy mogli prowadzić akcje militarne i odwetowe przeciwko okupantowi. Wróg bał się bowiem wchodzić w głąb lasu, gdyż nie znał jego topografii i struktury. Dzisiaj ta funkcja napotyka już na różne trudności, gdyż obszary leśne się kurczą i są poprzecinane drogami. Niemniej jednak współczesne Wojska Obrony Terytorialnej (stanowiące piąty rodzaj polskich sił zbrojnych) uczą się bytować w lesie, szkolą się w nim i poznają lokalne tereny leśne, które mogłyby posłużyć do walki obronnej.

Lasy pełnią też funkcje w materialnym utrzymaniu człowieka, w tym m.in. jego fizycznego bytu (i innych jego wymiarów), dostarczając mu utrzymania (różne formy zbieractwa w celach zarobkowych). Pomijając tu funkcje gospodarcze lasów (które nie należą do tematu tego artykułu), to w sensie społecznym las może być też traktowany jako miejsce pracy (np. zawód leśnika i inne pokrewne „leśne” zawody). Las zajmuje zatem miejsce $\mathrm{w}$ społecznym procesie pracy.

\subsection{Funkcje psychiczne}

Kolejnym zespołem funkcji są te o charakterze psychicznym. Funkcje psychiczne są pomijane w literaturze ekologicznej i przyrodniczej. Na tego typu tematy wypowiada się literatura psychologiczna z zakresu psychologii środowiskowej czy ekopsychologii (psychologii ekologicznej), choć znajduje się ona jeszcze na etapie swojego kształtowania i jest w różny sposób rozumiana i postrzegana przez poszczególnych autorów (Stokols and Altman 1987; Winter 1996; Bell et al. 2001; Bańka 2002; Koger and Winter 2010; Steg et al. 2012; Gifford 2014). Choć przywołane publikacje nie są poświęcone wprost zagadnieniu lasu, to na podstawie tego typu opracowań można dokonać pewnych uogólnień i stwierdzić, że las wpływa nie tylko na zdrowie fizyczne, lecz także psychiczne. Ludzkie zdrowie ma bowiem wymiar psychofizyczny. Podobnie jest z rozwojem człowieka, który jednocześnie przebiega w tych dwóch płaszczyznach. Do tego dochodzi też płaszczyzna społeczna, gdyż ludzie kształtują swoją psychikę i zachowania w ramach wpływu społeczeństwa (i sytuacji społecznych), a więc funkcje psychiczne mają zawsze swój wymiar psychospołeczny.

Nawiązując do obszarów badawczych społecznej psychologii środowiskowej (Bańka 2002, 26), można stwierdzić, że problematyka leśna dotyczy wpływu na psychikę i zachowanie człowieka:

- fizyczno-przestrzennych reprezentacji środowiska leśnego (takich jak: dźwięk, kształt czy przestrzeń) oraz jego ożywionego i nieożywionego środowiska uwzględniającego także krótkoterminowe skutki adaptacyjne takich oddziaływań na życie jednostki tudzież całych grup ludzkich czy większych społeczności;

- czynników środowiska leśnego oddziałujących na samoocenę, dobrostan 
oraz poczucie: rozwoju, tożsamości, panowania nad otoczeniem i swobody działania;

- w kontekście pozytywnego jego funkcjonowania w środowisku społecznym.

Naturalnie tego typu obszary odniesione do oddziaływania lasu domagają się badań empirycznych z zakresu psychologii. Do tej pory nie było takich kompleksowych badań nad wpływem lasu na różne elementy ludzkiej psychiki i zachowań ludzi. Można jednak już teraz, na podstawie niektórych (przywołanych wcześniej) publikacji z zakresu literatury psychologicznej - jak i z własnej obserwacji i doświadczenia dość ogólnie stwierdzić, że las sprzyja jednoczesnej regeneracji sił fizycznych, ale i psychicznych czy umysłowych jednostki, korzystnie wpływając na zdrowie psychiczne (psychofizyczne) całej populacji. Kontakt z lasem, z jego mikroklimatem i naturalnym pięknem, zapachem olejków eterycznych, dźwięków natury oraz odpoczynek w nim pozwalają ludziom uspokoić i wyciszyć się, odreagować stres, zgiełk, hałas i odciąć się od innych problemów życia w wielkich aglomeracjach miejskich. Las ma zatem pozytywny wpływ na rozwój ludzkiej osobowości i psychiki, a także sfery emocjonalnej. Ekopsycholodzy podkreślają współzależność człowieka z przyrodą, kontakt zaś z lasem (z jego przyrodniczym bogactwem) niewątpliwie sprzyja w odbudowywaniu więzi z naturą i utrzymywaniu z nią pożądanych relacji. Kontakt z przyrodą jest człowiekowi niezbędny również w aspekcie psychicznym i emocjonalnym. Dzięki kontaktowi z naturą (co może się odbywać m.in. za pośrednictwem lasu) ludzie mogą odczuwać pozytywny nastrój i zadowolenie, a to z kolei przyczynia się do odczuwania przez nich szczęścia oraz wpływa na ich prawidłowy rozwój i kształtowanie zdrowia psychofizycznego. Oderwanie się współczesnego człowieka od przyrody (co widać obecnie chociażby na przykładzie niszczenia przyrodniczych zasobów i terenów leśnych) - zdaniem ekopsychologów - prowadzić będzie do wielu lęków, nałogów i innych problemów natury psychicznej. W wymiarze społecznym może to przełożyć się na zakłócenia w funkcjonowaniu ludzi, ich adaptację i zachowania w obrębie społeczności, a w ujęciu jeszcze szerszym - całego społeczeństwa.

\subsection{Funkcje duchowe (duchowo-poznawcze)}

Następnym ważnym zespołem funkcji są te, które odpowiadają za duchowy (w tym i poznawczy) rozwój społeczeństwa przebiegający w różnych płaszczyznach ludzkiej rzeczywistości. W sensie socjologicznym, każda z opisanych niżej szczegółowych funkcji ma charakter kulturowy, a więc też i kulturotwórczy. Szczególnie wiedza stanowiąca wytwór ludzkiej aktywności intelektualnej uznawana jest za ważny element kultury duchowej (niematerialnej), chociaż nie jest jej jedynym składnikiem. Rozwój duchowy człowieka (osoby) jest bowiem wielowymiarowy i prowadzi do intensyfikacji różnych form kultury (nie tylko duchowej, lecz także materialnej - np. konkretnych wytworów nauki, techniki, architektury, sztuki).

Las pełnił i nadal pełni funkcje kulturotwórcze. Postrzeganie lasu może mieć wymiar duchowy, a nawet religijny (animistyczny). Tak było w odległej przeszłości, gdy poszczególnym składnikom dzikich lasów czy puszczy (np. drzewom i innym roślinom, polanom czy zwierzętom leśnym) nadawano niemal sakralny charakter i oddawano cześć. Znajdowało to odzwierciedlenie w mitologii społeczności (np. mitologii greckiej, rzymskiej, słowiańskiej). Obecnie tego typu postrzeganie lasu czy dżungli można zaobserwować jeszcze w nielicznych małych społecznościach myśliwsko-zbierackich, znajdujących się np. na obrzeżach Ameryki Południowej czy chociażby w Indiach (święte gaje). Ale i we współczesnych, rozwiniętych społeczeństwach las oddziaływał i nadal oddziałuje na wyobraźnię i inwencję twórczą wielu pokoleń artystów, pisarzy czy muzyków, a nawet inżynierów. Zachwyt nad naturą, jej pięknem, które bardzo dobrze oddaje las (zwłaszcza pierwotny), stanowił inspirację do powstania wielu 
dzieł o różnorodnych formach, np. z dziedziny literatury, malarstwa, architektury, rzeźbiarstwa, a nawet muzyki (Wiśniewski i Kiełczewski 2004). Treść tych dzieł, ich ponadczasowy przekaz są ważnymi składnikami kultury duchowej społeczeństwa stanowiącej dziedzictwo, inspirujące ludzi i nowe pokolenia twórców.

Niepowtarzalne piękno lasu inspiruje zarówno twórców, jak i generalnie wielu ludzi, pełniąc dla nich ważne funkcje estetyczne, zaspokajając potrzeby doznań estetycznych, upiększając też ludzkie otoczenia społeczne. Dlatego też wielu ludzi odwiedza las nie tylko ze względów zdrowotnych, lecz także po to, by obcować z naturalnym pięknem.

Badanie lasu prowadzi też do poszerzenia wiedzy naukowej. Dotykamy tu zagadnienia roli lasu w rozwoju nauki i dydaktyki stanowiącej wytwór ludzkiej aktywności intelektualno-poznawczej. Las spełnia bowiem funkcje naukowe i dydaktyczne. Dotyczą one badania pierwotnych praw przyrody, są przedmiotem badań dla wielu dyscyplin z dziedzin nauk leśnych, przyrodniczych, a nawet technicznych. Pośrednio las może inspirować też przedstawicieli innych dziedzin nauki, np. dyscyplin humanistycznych oraz społecznych - wszak wielu twórców z filozofii i etyki środowiskowej czy szeroko pojmowanej (np. w krajach anglosaskich) ekologii humanistycznej i społecznej wywodzi się z kręgów leśników i przyrodników.

Las, choć jest bardzo dobrze zbadany, do dzisiaj potrafi zaskakiwać wielu naukowców, kryje bowiem jeszcze w sobie wiele niezbadanych obszarów. Taką rolę spełniają obecnie np. parki narodowe. Są one nie tylko najwyższą prawną formą ochrony przyrody w Polsce, lecz także miejscem badań naukowych i realizacji procesu dydaktycznego (edukacja ekologiczna), upowszechniającego wiedzę o pierwotnym lesie i przyrodzie. Uczą one także, jak ludzie powinni odnosić się do natury i zachowywać w lesie. Pełnią zatem ważne (powiązane z dydaktycznymi) funkcje wychowawcze (wychowanie proekologiczne), wyrabiające potrzebę i chęć ochrony przyrody, łącząc to $\mathrm{z}$ wiedzą z zakresu środowiska (pedagogika środowiskowa). Również rezerwaty przyrody oraz inne formy i miejsca ochrony przyrody pełnią podobną rolę (Kiełczewski i Wiśniewski 1982, 93-128). Ponadto poznawanie lasów (puszczy, parków narodowych czy lasów ukształtowanych przez człowieka itp.), zarówno tych znajdujących się w najbliższej nam okolicy, jak i położonych w dalszych zakątkach kraju, pozwala też poznać własny kraj. Lasy zatem pełnią też funkcje krajoznawcze.

Wspomniane funkcje dydaktyczno-wychowawcze lasów są nie do przecenienia. Obecnie las traktuje się jako naturalną - i co ważne - efektywną szkołę edukacji ekologicznej społeczeństwa będącą swoistą „żywą lekcją”. Ma ona (oprócz funkcji typowo poznawczych) także swój wymiar aksjologiczno-normatywny stanowiący ważny składnik kultury duchowej społeczeństwa (kształtujący przemyślenia ludzi, ich przekonania, idee i zachowania - również w kontekście środowiskowym). Uczy ona, że las jest wartością nie tylko użytkową, lecz także wsobną oraz kulturową, będącą historycznym źródłem naszej cywilizacji, którą należy ochronić i zachować dla obecnych i przyszłych pokoleń (Przybylska 2005, 103). Nie można go zatem dowolnie niszczyć, gdyż zasługuje na ludzki szacunek. Stąd też las jest ważnym elementem edukacji dla zrównoważonego rozwoju.

Pomiędzy tymi omówionymi trzema zespołami funkcji fizycznych, psychicznych i duchowych, które składają się na funkcje społeczne (społeczno-kulturowe) lasu, zachodzą wzajemne oddziaływania. Są one bowiem wzajemnie ze sobą zintegrowane. Wpływają zatem na rozwój kultury fizycznej (materialnej), jak i niematerialnej, czyli duchowej. I tak przykładowo funkcje fizyczne, np. w aspekcie zdrowotności, kształtują zarówno zdrowie fizyczne jednostki, jak i psychiczne (funkcje psychiczne). Realizacja funkcji duchowych jest możliwa dzięki dobrze ukształtowanej i funkcjonującej sferze 
psychicznej (a w zasadzie psychofizycznej) człowieka w społeczeństwie. Człowiek bowiem jest istotą psychofizyczną. Funkcja turystyczno-rekreacyjna powiązana jest z funkcją krajoznawczą (a nawet patriotyczną i obronną; poprzez lasy poznajemy nasz kraj i zaczynamy doceniać Ojczyznę, którą warto bronić) oraz z funkcją dydaktyczno-wychowawczą. Można bowiem poznawać las w ramach zielonej szkoły, leśnych ścieżek dydaktycznych czy wycieczek do lasu (Będkowska 2005), za pomocą których uzupełniamy edukację szkolną i uczymy się przebywać i chronić las (wychowanie proekologiczne). Funkcja estetyczna (piękno lasu) oddziałuje na funkcje psychiczne, kształtując chociażby u ludzi pozytywny nastrój. Nadaje się też do wykorzystania w procesie wychowawczym jako jeden $\mathrm{z}$ argumentów podbudowujących ludzką motywację do ochrony leśnych obszarów (naturalnie z wykorzystaniem funkcji psychicznych). To tylko niektóre z przykładów, które można mnożyć. Las spełnia bowiem wiele większych i pomniejszych funkcji społecznych wzajemnie na siebie oddziałujących (co obrazuje obustronna strzałka na rys. 4 i innych rysunkach).

\section{4. Środowisko społeczno-przyrodnicze lasu i jego funkcje a bezpieczeństwo środowiskowe (ekologiczno-zdrowotne)}

Funkcje społeczno-kulturowe lasu (obok uwarunkowań typowo przyrodniczych ekologiczno-środowiskowych) kształtują też bezpieczeństwo. I nie dotyczy to tylko zasygnalizowanej funkcji obronnej, mającej wpływ na militarne bezpieczeństwo narodowe, ale przede wszystkim odnosi się do bezpieczeństwa środowiskowego. Niewątpliwie las, stanowiący integralny element środowiska społeczno-przyrodniczego, sprzyja kształtowaniu bezpieczeństwa w tym obszarze, chroniąc środowisko (w tym i jego równowagę) oraz ludzkie zdrowie (oddziałując na bezpieczeństwo ekologiczno-zdrowotne). Wynika to m.in. z funkcji ochronnej i zdrowotnej lasu.
Przypomnijmy, iż bezpieczeństwo środowiskowe (nazywane też bezpieczeństwem ekologicznym) można zdefiniować jako „trwały stan wolny od (negatywnych skutków) zagrożeń naruszających dynamiczną równowagę (ekologiczną) w środowisku naturalnym (społeczno-przyrodniczym), umożliwiający (pozytywną) zdolność do jej ciągłego podtrzymywania, zapewniający istnienie i dalszy rozwój oraz poczucie takiego stanu" (definicja własna; Ciszek 2016, 17).

Powyższa definicja bardzo dobrze wpisuje się w rozważania podjęte $\mathrm{w}$ pierwszej części niniejszego artykułu, w której omówiono specyfikę ludzkiego środowiska. Otóż tak rozumiane bezpieczeństwo środowiskowe człowieka jest kształtowane przez środowisko przyrodnicze i środowisko sztuczne (ludzkie, czyli społeczno-kulturowe). Dopiero te dwa typy środowisk razem wzięte stanowią naturalne środowisko życia człowieka - osoby ludzkiej (środowisko ludzkie). Dlatego też należy zagwarantować w płaszczyźnie politycznej i społeczno-gospodarczej naszej cywilizacji takie warunki rozwoju, w efekcie których te dwa dynamiczne elementy (czynniki) - przyrodniczy (wytwór natury) i sztuczny (ludzki wytwór) będą pozostawały we względnej równowadze (zob. rys. 1). Ów pożądany stan można byłoby uznać za homeostazę systemu środowiska społeczno-przyrodniczego gwarantujący mu bezpieczeństwo. Natomiast zaburzenie tej pożądanej równowagi na przewagę któregoś z tych dwóch czynników (elementów) będzie (w dłuższej perspektywie czasowej) szkodliwe (negatywne) dla ludzkiego bezpieczeństwa (niebezpieczne). Natomiast wszelkie trendy starające się podtrzymywać tę równowagę należy traktować jako korzystne (pozytywne) dla tak pojmowanego bezpieczeństwa (nawet w sytuacji, gdy pociągają za sobą pewne ograniczenia w rozwoju gospodarczym kraju lub generują poważne nakłady finansowe). Można nawet stwierdzić, iż tak pojmowana równowaga jest równoznaczna $\mathrm{z}$ koncepcją zrównoważonego rozwoju. 
Warto nadmienić, że w przedstawionej powyżej koncepcji bezpieczeństwa środowiskowego ściśle się z nią wiąże (a nawet się w niej mieści) problematyka ludzkiego zdrowia (bezpieczeństwo zdrowotne). Równowaga ekologiczna w środowisku społeczno-przyrodniczym w odpowiedni bowiem sposób oddziałuje na stan zdrowia jednostki, jak i całych populacji (społeczeństwa), kształtując ich bezpieczeństwo. Tak rozumiane bezpieczeństwo ekologiczne (równowaga ekologiczna w środowisku przyrodniczym człowieka) sprzyja zatem ochronie i kształtowaniu ludzkiego zdrowia. Trudno bowiem urzeczywistnić skutecznie jakąkolwiek koncepcję bezpieczeństwa zdrowotnego bez uprzedniego zadbania o odpowiednią jakość środowiska otaczającego człowieka (bezpieczeństwo ekologiczne jest niezbędnym i koniecznym warunkiem zaistnienia bezpieczeństwa zdrowotnego). Bezpieczeństwo zdrowotne jest więc $\mathrm{z}$ jednej strony efektem bezpieczeństwa ekologicznego (bazującego na równowadze ekologicznej), ukierunkowanego przecież na podtrzymywanie istnienia i dalszego rozwoju, które w przypadku człowieka zawsze dotyczy jego życia i zdrowia. Z drugiej zaś strony, troska o bezpieczeństwo zdrowotne ludzi zakłada jednocześnie dbanie o odpowiednią jakość środowiska przyrodniczego, w którym oni żyją. Można więc stwierdzić, że tak wąsko pojmowane bezpieczeństwo ekologiczne (jako ochrona i kształtowanie środowiska naturalnego - równowagi ekologicznej) plus bezpieczeństwo zdrowotne (ochrona i kształtowanie ludzkiego zdrowia) łącznie tworzą szeroko pojmowane bezpieczeństwo środowiskowe ${ }^{1}$ (bezpieczeństwo ekologiczno-zdrowotne) - zob. rys. 5 .

Dotyczy to również problematyki leśnej. Las jest bardzo ważnym elementem środowiska społeczno-przyrodniczego, które trzeba chronić. Ludzie jednak potrzebują do swojego życia i dalszego rozwoju przekształconego kulturowo środowiska przyrodniczego, dopasowanego do ich potrzeb, co z kolei będzie pociągało za sobą nieuchronne zniszczenia i przekształcenia w zasobach leśnych. Muszą one jednak być racjonalnie uzasadnione i ściśle kontrolowane. Nadmiernie bowiem przekształcone i zniszczone lasy mogą doprowadzić do bariery rozwoju cywilizacyjnego, negatywnie wpłynąć na zdrowie ludzkich populacji oraz - w skrajnym przypadku (globalnych i nieodwracalnych zmian w środowisku przyrodniczym) - unicestwić nawet samego człowieka. Natomiast dbanie o odpowiednią jakość obszarów leśnych pozytywnie będzie wpływało na ludzkość. Warto też zachować dzikie pokłady dziedzictwa przyrodniczego

1 Tak szeroko pojmowane bezpieczeństwo środowiskowe (jako bezpieczeństwo ekologiczno-zdrowotne) bardzo dobrze wpisuje się w uprzednio sformułowaną definicję bezpieczeństwa środowiskowego, którą można byłoby uzupełnić (dodanym w nawiasie wyrażeniem) jako „trwały stan wolny od (negatywnych skutków) zagrożeń naruszających dynamiczną równowagę (ekologiczną) w środowisku naturalnym (społeczno-przyrodniczym), umożliwiający (pozytywną) zdolność do jej ciągłego podtrzymywania, zapewniający istnienie i dalszy rozwój (w tym życie i zdrowie) oraz poczucie takiego stanu" (definicja własna).
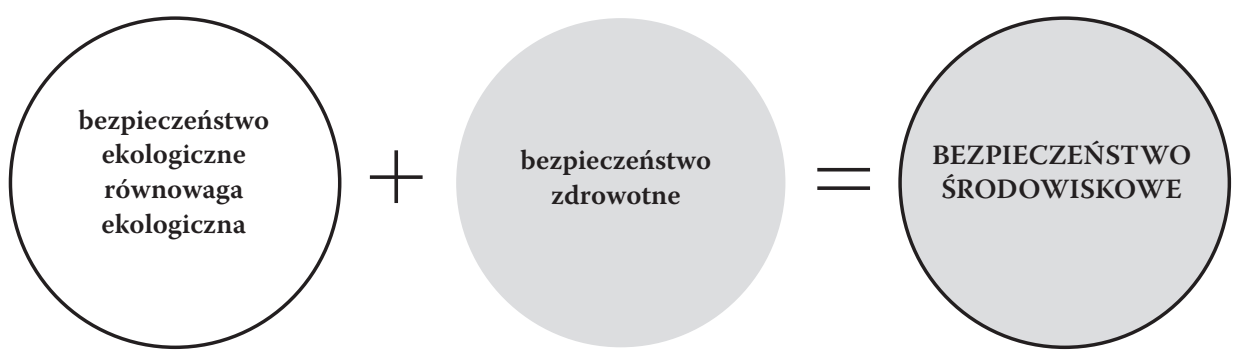

Rysunek 5. Elementy składowe szeroko pojmowanego bezpieczeństwa środowiskowego 
lasów (w tym lasów pierwotnych i naturalnych), których nie należy przekształcać. Ich użytkowanie warto zastąpić chociażby sadzeniem nowych lasów gospodarczych, na bazie których prowadzona będzie gospodarka leśna. Ludzkie środowisko społeczne nie bytuje bowiem w próżni, lecz jest nadbudowane i osadzone w (ożywionej i nieożywionej) przyrodzie (Ciszek 2013, 234), którą należy chronić, gdyż oddziałuje na życie i zdrowie człowieka.

\section{Zakończenie}

W niniejszym artykule las ukazano jako ważny element środowiska społeczno-przyrodniczego człowieka. Co ważne, jest to element aktywny, oddziałujący na społeczeństwo, chociażby poprzez spełniane przezeń wielorakie społeczne funkcje, które kształtują również bezpieczeństwo środowiskowe. Są one na tyle ważne, że należy podjąć wysiłki społeczno-polityczne i etyczno-prawne, aby to naturalne dziedzictwo zachować dla obecnych, jak i przyszłych generacji ludzi, a więc zgodnie $\mathrm{z}$ ideą zrównoważonego rozwoju. Utrata obszarów leśnych stanowić będzie nie tylko niepowetowaną stratę o charakterze przyrodniczo-ekologicznym i gospodarczym, lecz także społecznym. Las stanowi też wartość kulturową, a nie tylko użytkową, o którą trzeba zabiegać i którą trzeba kultywować. Dotyczy to zarówno lasów całkowicie naturalnych (pierwotnych), jak i tych ukształtowanych i sadzonych przez człowieka.

\section{Bibliografia}

Bańka, Augustyn. 2002. Społeczna psychologia środowiskowa. Warszawa: Wydawnictwo Naukowe SCHOLAR.

Bell, Paul A., Thomas C. Greene, Jeffery D. Fisher, and Andrew Baum. 2001. Environmental Psychology. New York: Harcourt College Publishers.

Będkowska, Hanna. 2005. Wycieczka do lasu: poradnik dla nauczycieli, rodziców i opiekunów. Warszawa: MULTICO Oficyna Wydawnicza.

Bowden, Gary. 2017. "From Environmental to Ecological Sociology." TASA: The Australian Sociological Association, Accessed December 20, 2017: 1-14. https://tasa.org.au/wp-content/uploads/2011/01/ BOWDEN_a.pdf.

Bubolz, Margaret M., and M. Suzanne Sontag. 1993. "Human Ecology Theory." In Sourcebook of Family Theories and Methods: A Contextual Approach, edited by Pauline G. Boss, William J. Doherty, Ralph LaRossa, Walter R. Schumm, and Suzanne K. Steinmetz, 419-448. New York: Plenum Press. Ciszek, Mariusz. 2013. Filozofia ekologii rodziny ludzkiej w systemie środowiska spotecznego, kulturowego i przyrodniczego: Studium społeczno-filozoficzne z zakresu bezpieczeństwa ekologicznego. Siedlce: Wydawnictwo Uniwersytetu Przyrodniczo-Humanistycznego w Siedlcach.

Ciszek, Mariusz. 2016. „Bezpieczeństwo ekologiczne (środowiskowe) i kultura bezpieczeństwa ekologicznego (środowiskowego)." Kultura Bezpieczeństwa 5: 11-22.

Dołęga, Józef M. 2003. „Słowo o środowisku społeczno-przyrodniczym." W Wychowanie do poszanowania środowiska społeczno-przyrodniczego, red. Jacek W. Czartoszewski, i Janusz M. Kotowski, 7-11. Warszawa: VERBINUM Wydawnictwo Księży Werbistów.

Gifford, Robert. 2014. Environmental Psychology: Principles and Practice. Colville: Optimal Books. Kiełczewski, Bohdan, i Jerzy Wiśniewski. 1982. Las w środowisku życia człowieka. Warszawa: Państwowe Wydawnictwo Rolnicze i Leśne.

Koger, Susan M., and Deborah D. N. Winter. 2010. The Psychology of Environmental Problems: Psychology for Sustainability. New York: Psychology Press.

Korbel, Janusz. 2005. Człowiek $i$ Las: o ochrone Puszczy Białowieskiej. Lipsk-Białowieża: Pracownia Architektury Żywej.

Mazurski, Krzysztof R. 2009. „Środowisko.” W Stownik bioetyki, biopolityki i ekofilozofii (w kreggu zagadnień $i$ moralnych problemów bezpieczeństwa), red. Mariusz Ciszek, 260. Warszawa: Polskie Towarzystwo Filozoficzne.

Olaczek, Romuald. 1999. Stownik szkolny. Ochrona przyrody i środowiska. Warszawa: Wydawnictwa Szkolne i Pedagogiczne.

Przybylska, Krystyna. 2005. „Funkcje lasu.” Problemy Ekologii 9(2): 101-103.

Pyłka-Gutowska, Ewa. 2000. Ekologia z ochronq środowiska. Warszawa: Wydawnictwo Oświata. 
Steg, Linda, Agnes E. van den Berg, and Judith I.M. de Groot (eds). 2012, Environmental Psychology: An Introduction. Chichester-Malden: Wiley-Blackwell. Stokols, Daniel, and Irwin Altman (eds). 1987. Handbook of Environmental Psychology. New York: John Wiley \& Sons.

Winter, Deborah D. N. 1996. Ecological Psychology: Healing the Split Between Planet and Self. New York: HarperCollins College Publishers.
Wiśniewski, Jerzy, i Bohdan Kiełczewski. 2004. Kulturotwórcza rola lasu. Poznań: Wydawnictwo Akademii Rolniczej im. A. Cieszkowskiego w Poznaniu. 